\title{
Osmanlı İmparatorluğu Dönemi Türk Askeri Havacılığı
}

\section{Osman Yalçın **}

Öz

Uçağın ilk uçuşu olarak kabul edilen 17 Aralık 1903 tarihinde Wright Kardeşlerin uçuşundan sadece altı yıl sonra İstanbul semalarında önce Voisin tipi uçakla Baron de Catters takiben kendi adıyla anılan uçağı ile Bleriot uçuşlarını yapmışlardır. Osmanlı askeri, bir komisyon teşkil ederek konuyu incelemiş ve uçakların yakın gelecekteki önemi sebebiyle Osmanlı ordusunda yer alma fikri de raporda yer almıştır. Kısa süre sonra Türk havacılığını kurma çalışması başlatılmış ve 1 Haziran 1911'de kurulan "Tayyare Komisyonu" ile Osmanlı havacilı̆̆ı teşkil edilmiştir. Teşkilat, pilot, rasıt ve teknik eğitim, uçak alınması, havaclık merkezinin nerede kurulacağına karar verilmesi, teçhizat, hava savunma ihtiyacı ve millî imkânlarla uçak üretimi gibi birçok sorun kısa zamanda çözümlenmiş ve önemli adımlar atılmıştır. Çalışmada Osmanlı havacılığının kuruluşu ve teşkilatlanması süreci incelenmişsir. Bu kapsamda; Osmanlı askeri havacılığının kuruluş gerekçeleri, teşkilat, personel temini, uçak, balon ve teçhizat tedariki, uçak fabrikası kurma çalışmaları, harekât görevleri ve Almanlarla iş birliğinin Türk havacıllğına tesirleri incelenmiştir. Şüphesiz çalışmadan elde edilen sonuç, dört kişilik komisyon ile kurulan Türk Havacılığının, 33 yıl sonra müstakil kuvvet seviyesine yükselmesi olmuştur.

\section{Anahtar Kelimeler}

Osmanlı Havacilığı, Türk Hava Kuvvetleri, Süreyya İlmen, uçak, balon, Trablusgarp Savaşı, Balkan Savaşları.

\footnotetext{
Geliş Tarihi: 04 Nisan 2016 - Kabul Tarihi: 05 Nisan 2017

Bu makaleyi şu şekilde kaynak gösterebilirsiniz:

Yalçın, Osman (2021). "Osmanlı İmparatorluğu Dönemi Türk Askeri Havacıllğı". bilig - Türk Dünyası Sosyal Bilimler Dergisi 96: 147-176.

" Doç.Dr.(E.)Hv.Öğ.Kd.Alb., İstanbul Rumeli Üniversitesi, MYO,Ulaştırma Hizmetleri Bölümü, Sivil Hava Ulaştırma İşletmeciliği - İstanbul/Türkiye ORCID ID: 0000-0002-6259-6490 osman.yalcin@rumeli.edu.tr
} 


\section{Türklerin Kült ve Mitolojisinde Gökyüzü ve Uçma Özlemi}

Türklerin gökyüzüne olan büyük ilgileri, Türk devlet hayatında da kendini gösterir. Bu kapsamda, Türk devletlerinin bayraklarında gökyüzündeki varlıklar yoğun olarak yer almıştır. Örneğin Avrupa Hun İmparatorluğu, Gazneli Devleti ve Büyük Selçuklu İmparatorluğu bayraklarında kuş resmi bulunmaktadır. İnançta "Gök Tanrı" olarak tek tanrı inancı vardır. Keza Selçuklu dönemi mezar ve kümbetlerde de benzeri işaretler yaygındır. Konya İnce Minare, Erzurum Camisi'nde bulunan kartal kabartmaları bunlardandır. Günümüzde de bazı Türk devletlerinin de bayraklarında ay, güneş ve yıldız gökyüzüne olan ilginin yansımalarıdır. Çift başlı kartal Selçukluların sembolü olmuştur. Bütün bu izler Türklerin havacıllğa olan özlemini ifade ettiği gibi aynı zamanda değer verdiği kutsallarını yüksekte tutma kültürünün de bir sonucudur (Genkur 50.Yıl: 17, 50, 172, Yalçın 2017: XV, Yalçın 2008: 1).

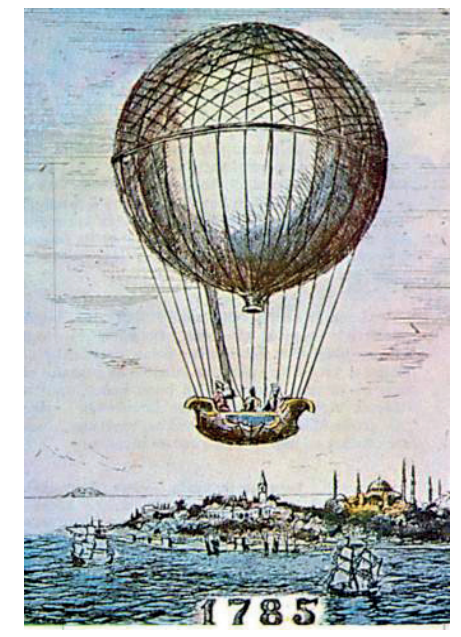

Resim 1. Istanbul'da İlk Balon 1785

\section{Türklerde Uçma Teşebbüsleri}

Türk havacilığının tarihi oldukça eskidir. Gökyüzünü araştırmaya yönelik, uçuş ve astronomi alanında önemli çalışmalar yapılmıştır. Cevheri, 10021010 yılları arasında Nişabur Ulu Cami'nde uçmaya teşebbüs etmiştir. Kanatlar Cevherî̀yi taşıyamamış ve şiddetle yere çarparak vefat etmiş ve ilk Türk hava şehidi kabul edilmektedir. 
Türk havacilğgında Doğulu Siracettin'in 1159'da İstanbul'da yaptığı uçuş ikinci olaydır. Bir şenlikte, uçacağını iddia etmiş ve kanat takarak kendini hipodromda, çok yüksekten aşağıya bırakmıştır. Bir süre havada süzülüp yere çakılmış ve hayatını kaybetmiştir (Yalçın 2009: 3,4, Öztuna vd. 1971: 18).

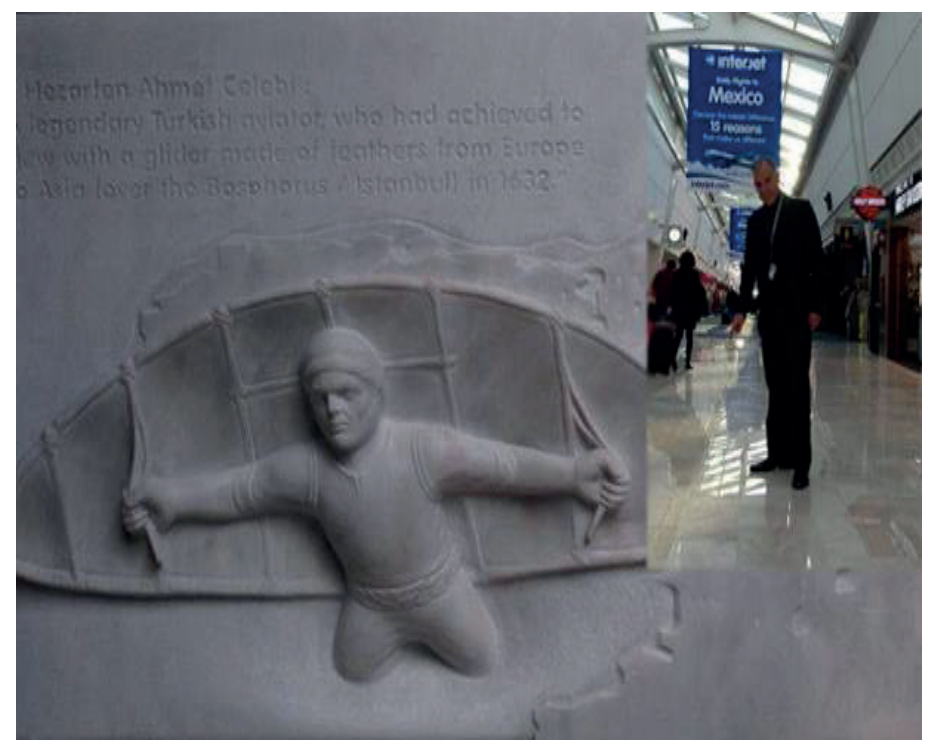

Resim 2. Hazerfen Rölyefi ABD JFK Terminali (Star Gaztesi:25.01.2015)

Osmanlı İmparatorluğu zamanında Hezârfen Ahmet Çelebi bir kanatla Galata Kulesi'nden Üsküdar Doğancılar'a kadar uçmayı başarmış ve Sultan IV. Murat tarafından ödüllendirilmiştir. (Danışman 1971: 288,289). Son zamanlarda Hezarfen Ahmet Çelebi'nin uçuşunu temsil eden rölyef, New York'un üç hava alanından biri olan JFK Havalimanına terminalinin en çok görünen bölgesine işlenerek bu tarihi uçuşun dünyaya tanıtımı yapılmıştır (ensonhaber:22.09.2016; airnewstimes.com:22.09.2016; star.com.tr: 22.09.2016; Star Gazetesi 25.01.2015:1)

Bu dönemdeki bir diğer gelişme; Lâgari Hasan Çelebi'nin 70 kilo kadar barutun itme gücüyle desteklenen roket-fişseğin ateşlenmesi ile havalanmasıdır. Lagari bu yükselişle Sarayburnu'ndan Sinanpaşa Kasırı önünde yine paraşüt benzeri bir sistemi kullanarak denize inmiştir. Sultan IV. Murat tarafından ödüllendirilmiştir (Yalçın 2004: 1,2, Kansu vd. 1971: 35-40). 


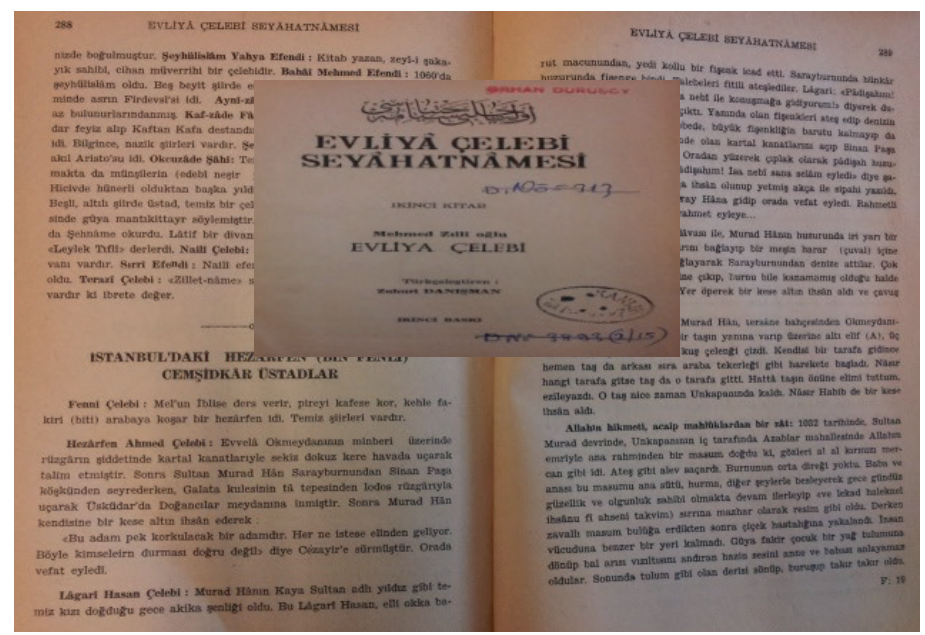

Resim 3. Evliya Çelebi’nin Seyahatnamesinde Uçuş

Erzurumlu İbrahim Hakkı'nın Marifetnâme isimli eserinde astronomi ve uzaya ait geniş bilgiler yer alır. 19. yüzyılda Trabzon'un Of kasabasında yaşayan Veli Direko ile yakın arkadaşı Ahmet Hoca’nın kuşların kanadından esinlenerek yaptıkları kanatla uçtukları bilinir. 1861 yılında Bebekli Atıf Bey'in kanat takarak Bebek halkına uçacağını söylemesi ve bir süre süzüldükten sonra düşmesi, Türk havacılık tarihinde yer almaktadır (Yalçın 2008: 3, Kansu vd. 1971: 88).

Türk zabiti olan Mehmet Rüştü'nün 1897 yllında aldığı balonculuk eğitimi, Türk havacılık tarihi bakımından eğitim alanında ilktir. Mehmet Rüştü ilk Türk askerî havacısıdır (Hava Mecmuası 15 Mayıs 1927: 134, Kansu vd. 1971: 67).

\section{Osmanlı Askeri Havacılığının Kuruluşu ve Yapılandırılması}

18. asır balonların çağı olmuştur. 1783'de Montgolfier Kardeşlerin ilk balon uçuşundan iki yıl sonra bir İranlı ve iki Türk İstanbul'dan Bursa’ya balon uçuşu yapmıştır. Bu balon, Sultan I. Abdülhamit tarafindan Ayasoyfáda halkın gelişmelerden haberdar olması için teşhir ettirilmiştir (Yalçın 2008: 11). Türk yöneticilerin, havacılıktaki gelişmelere oldukça ilgi gösterdikleri anlaşılmaktadır.

Balonlar imalatından itibaren sık aralıklarla Osmanlı İmparatorluğu'nun başkentinde görünmesine rağmen (Kansu vd. 1971: 61-67), balona karşı 
yeterince istekli davranmayan Osmanlı idarecileri, uçakların yüzyılı olarak tanımlayabileceğimiz 20. yüzyılın başında ortaya çıkan uçağa büyük bir ilgi göstermiştir.

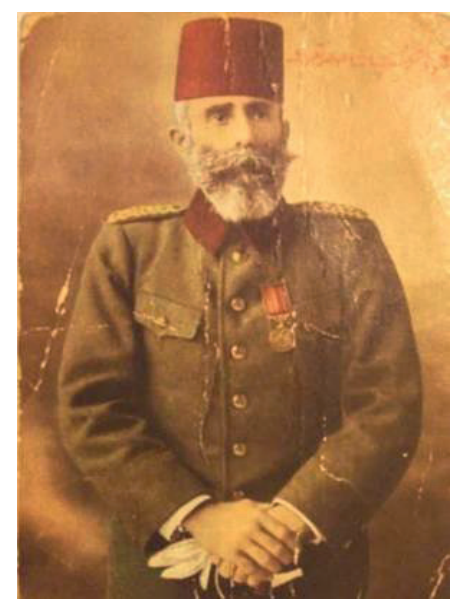

Resim 4. Harbiye Nazır Mahmut Şevket Paşa

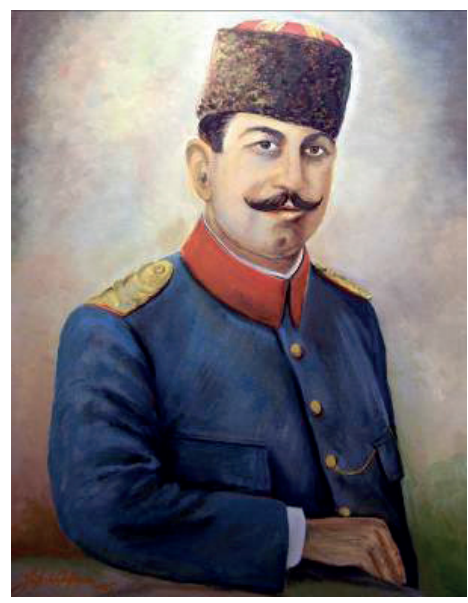

Resim 5. Kur.Yb.Süreyya (İlmen) Tayyare Kom.Bşk.

\section{Kuruluş gerekçeleri}

Dünyanın hızla silahlanması ve sömürgecilik yarışından endişelenen Osmanlı idarecileri, orduyu güçlendirmeye ve modernize etmeye daha fazla önem vermiş, askeri alandaki gelişmeler yakından takip edilmiştir. Bu gelişmelerden biri de havacilıktaki gelişmelerdir. Birçok olay, tatbikat ve gözlemler havacilığın gerekli olduğu kanaatini güçlendirmiştir. Uçağın hızla yaygınlaşması, Paris Havacılık Konferansında alınan kararlar, 1910 yılı Picardie ve Karıştıran Manevraları ile takiben İtalyanların Trablusgarp’te uçak kullanmaları bu kapsamdadır (Kural 1974: 54, 66, İlmen 1947: 18-20).

17 Aralık 1903 tarihinde Wright Kardeşlerin ilk uçuşundan kısa süre sonra uçak imalatçıları tasarımlarını satabilmek için pazarlamaya yönelik uçuş gösterileri yaptılar. Bu maksatla 1909 yılı Aralık ayında Baron de Catters Voisin tayyaresi ile Louis Blériot da Blériot tipi tayyaresiyle İstanbul'a gelerek uçuş gösterilerinde bulunmuşlardır. Louis Blériot, hava gösterisi sırasında küçük bir kaza yapmış ve uçağı kaza yapmıştır (Kurter 2009: 40, 41, Kansu vd. 1971: 115, Yalçın 2009: 10). Takiben 20 Aralık 1909'da bir Osmanlı Askerî Komisyonu teşkil edilir ve Komisyon bir rapor hazırlar. Bu raporda havacı- 
lığın kısa zaman sonra önemli olacağı tedbirlerin alınması ifade edilmiştir (Kural 1974: 2, Yalçın 2004: 5, 6, Yalçın 2008: 295, Beyoğlu 2015: 4).

Osmanlı Askeri Komisyonu raporunda; uçakların kısa süre içerisinde harp sahasının vazgeçilmez bir unsuru olacakları öngörüsü takdire değerdir. İngiliz Generali Haig'in 1914'de, “....Komutan için keşif yoluyla bilgi almanın bir yolu vardır ve bu da süvarinin kullanılmasıdır.” dediği bilinir (Erdoğan 1986: 32).

Osmanlıda askeri havacilığının kuruluşunda etkili bir diğer gelişme, 1910 yılında Trakya Karışıran taraflarında Osmanlı ordusu tarafından yapılan manevradır. Burada yeni gelişmekte olan uçakların keşif maksadıyla orduda kullanılabileceği değerlendirilmiştir (Yalçın 2008: 12, Keyüsk 1950: 7, 8). Yine bir diğer gelişme, 1910 yılında icra edilen ve Osmanlı İmparatorluğu’ nun Paris Sefareti'nin iştirak ettiği Uluslararası Balon Konferansı ve Hava Seferleri konferanslarıdır. Fethi Kural'ın arşiv belgelerinden derlediği çalışmasından anlaşıldığına göre havacılığın süratle gelişmekte olduğu ve buna yönelik tedbirler alınmasının gerekliliği ifade edilmiştir (Kural 1974: 60-73). Osmanlı askeri havacilığının kurulması öncesi oldukça önemli bir tespit ise 1910 yılında Paris Picardie manevralarına katılan Kur. Yzb. Mustafa Kemal'in de yer aldığı Osmanlı Heyeti ile katılan Fethi Bey’ in havacilığın önemine ve Osmanlı ordusunda teşkil edilmesine dair raporudur (Kansu vd., 1971: 116; Yalçın, 2016: 14, 15).

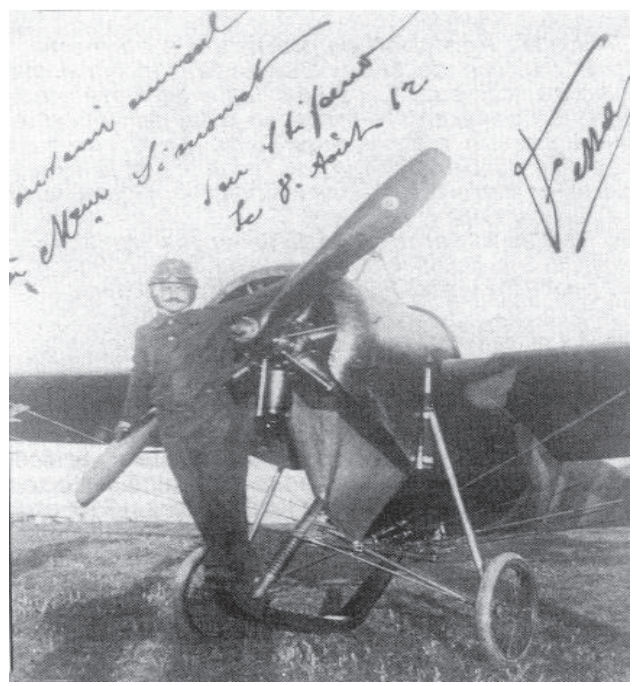

Resim 6. Yzb.Fesa Bey 


\section{Teşkilatlanma}

Askeri havacıl lğın kuruluş gerekçeleri ve ihtiyaçların ortaya çıkması ile bunların hayata geçirilmesi için bir havacılık teşkilatı ihtiyacı ortaya çıkmıştır. Osmanlı havacılığının teşkilatlanması sürecinde öne çıkan iki isim vardır. Bunlar dönemin Harbiye Nazırı Mahmut Şevket Paşa ile Kurmay Yarbay Süreyya (İlmen) Bey'dir. Mahmut Şevket Paşa Harbiye Nazırı olduktan sonra Osmanlı askeri havacılığının kurulması için birtakım tedbirler almıştır. Bu tedbirler şunlardır.

Askeri Ataşe olarak Berlin'de görevli Kur. Bnb. Enver Bey ile Paris'de bulunan Kur. Bnb. Ali Fethi (OKYAR) Bey'den havacilık alanında meydana gelen gelişmeleri incelemeleri istenir (Yalçın 2011: 1035, Kurter 2009: 43).

Genelkurmay 2.Şubeden, Kur. Yb. Süreyya Beyi havacıllkla ilgilenmesi için görevlendirilmiştir (Uçarol 1988: 22-24). Süreyya Bey anılarında “... İkinci Başkan Çürüksulu Mahmut Paşa beni çağırarak... bu hususta benim memur edildiğimi emretmişlerdir" (İlmen 1947: 19, Kurter 2009: 47) demektedir. Kur. Yb. Süreyya Bey, askerî ataşeler vasıtasıyla havacılık dokümanlarının alınması ve incelenmesi sonrasında havacılığın bir subay marifetiyle yürütülmeyecek kadar önemli olduğunu tespit etmiştir. Yarbay Süreyya Bey' in teklifi ile "Havacılık-Tayyare Komisyonu" nun kurulmasına karar verilmiştir. Süreyya Bey başkanlığında; İstihkâm Binbaşı Refik, İstihkâm Binbaşı Mehmet Ali ve İstihkâm Binbaşı Ahmet Zeki'den oluşan havacılık komisyonu kurulmuştur (Aydar 1948: 40, 41, Keyüsk 1950: 22, Taşdemir 2013: 929). 1960’lı yıllarda yapılan geniş bir çalışma ile kuruluş tarihi 01 Haziran 1911 olarak kabul edilmiştir. Bu tarih aynı zamanda günümüzde Türk Hava Kuvvetlerinin kuruluş tarihi olarak kutlanmaktadır. Komisyon, Harbiye Nezareti "Fen Kıtaları Müstahkem Mevkiler Genel Müfettişliği 2'nci Şubesi” ne bağlı çalışacaktı (Yalçın 2004: 9). Komisyon; uçak, balon ve teçhizat, temini, okul yapılması, teşkilat oluşturulması, personelin eğitilmesi gibi önemli birçok görevi üstlenmiştir.

20 Nisan 1912'de Fransa'dan satın alınan ve gelen uçakların Plt. Yzb. Fesa ile Plt. Tğm. Yusuf Kenan’a teslimi yapılmıştır. Bu tarih, ilk hava birliğinin kuruluşu olarak kabul edilme tarihidir (Keyüsk 1950: 26). Bu tarih Kural'ın eserinde 21 Mart 1912'dir.

İlk Türk hava birliklerinin çekirdeğini oluşturan yapı ordulara birer hava 
bölügünün dâhil edilmesidir. 25 Eylül 1912 tarihli Tayyare Mektebi ve Tayyare Bölükleri Teşkilatı oluşturulmuştur. Tayyare bölükleri iki takımdan, takımlar iki uçaktan meydana gelmektedir (Keyüsk 1950: 104-110, Yalçın 2008: 13, 14). Bu bölüklerin Batı'daki emsallerine göre sayı ve evsaflarının $1 / 4$ gibi oldukça düşük olduğunu da belirtmek gerekir.

1914 yılında Kıtaatı Fenniye şubesinde bağlantı değişikliği olmuş ve (Mevak1-1 Müstahkeme Müfettişliğinden Muhabere ve Muvasala Şubesine bağlanmış) havacılığın başına Bnb. Veli Bey getirilmiştir (Kansu vd. 1971: 159). Savaş yıllarında teşkilatta çok sık ve hızlı bir büyüme gerçekleşmiştir. Hava bölük sayısı İstanbul Tayyare Mektebi İstasyonu hariç 1915 yılı içerisinde yedi (7) adettir. Tayyare Mektebi ve Balon Müfrezesi dışında; Çanakkale, Irak, Uzun Köprü, Adana, Kafkas, Şam ve Keşan'da görev yapmaktadır (Yalçın 2004: 60, Yalçın 2008: 30, 31). 1915 sonlarına doğru Balkan yolları açıldığı için Almanyàdan bol miktarda uçak ve techizat gelmiştir. Plt. Yzb. Serno liderliğindeki Hava Kuvvetleri Müfettişliği, havacılık ile ilgili işleri koordine eden en üst makamdı.

16 Mayıs 1916'da kara ve deniz havacılığı, Genel Karargâh (Başkomutanlık) Havacılık İşleri Müfettişliği ve Umuru Havaiye Müfettişliği emrinde birleştirilmiştir (hvkk.tsk.tr). Türk uçuş personelinin ve uçak sayısının en üst seviyede olduğu zaman 1916 yılı sonudur. Toplamda 81 pilot, 57 rasıt ve 90 uçak mevcuttur. Türk havacılığının gelişmesinde, Birinci Dünya Savaşı yıllarında müttefiklerin, Türkiye'nin şartlarını değerlendirememeleri nedeniyle Türk havacılığını olumsuz etkilendiği, bazı aksi iddialara rağmen genel bir kabul hâline gelmiştir (ATASE. Hv. Hrkt. 1969: 68-71, Yalçın 2008: 30). Bu dönemlerde meteoroloji (Rasadat-ı Havaiye) alanında da ihtiyaç hasıl olmuş ve 1916 yılından itibaren hızla artmıştır. Rasadat-1 Havaiye kurulan merkezler; İstanbul, Vaniköy, Edirne, Gelibolu, İzmir, Eskişehir, Konya, Ankara, Zonguldak, Sinop, Adana, Beyrut, Kudüs ve Bağdat şehirleridir (Keyüsk 1950: 112-118, Yalçın 2009: 29).

1917 yılında bu bölüklerde 81 tayyare, 41 rasıt ve 61 pilot bulunmaktaydı (ATASE BDH 1441: 250, 27-5). 1918 yılı Temmuz ayı sonlarına doğru Umuru Havaiye Müfettişliği, Kuvvay-i Havaiye Müfettişliği olarak teşkilat değişikliği yapılmış ve bağımsız bir tümen seviyesi haline getirilmiştir. Yeni birimin emrine Tayyare, Balon, Rasadatı Havaiye ile Tayyare Topçu Müfettişlikleri verilmiştir. Yer olarak Galata Rıhtımında Merkez Hanının bir daire- 
sinde faaliyet gösterirken yeni teşkilat vesilesiyle Beyoğlu Tünel civarında 34 odalı Hidivyal Oteline nakledilmiştir (Keyüsk 1952: 252, Yalçın 2004: 205).

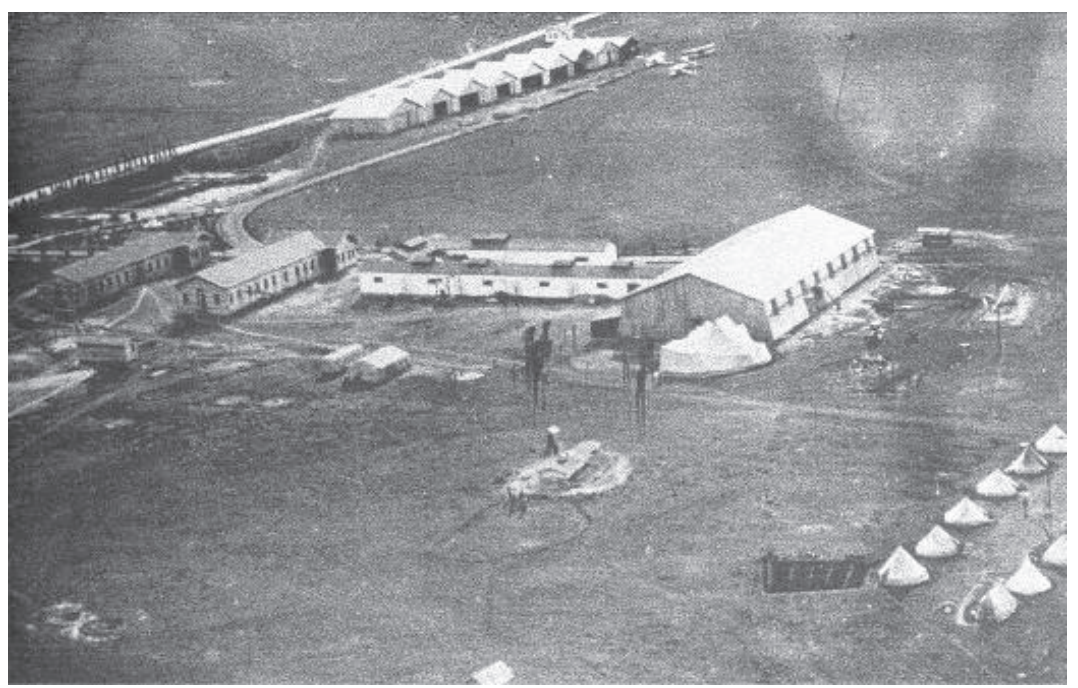

Resim 7. Yeşilköy Hava Okulu (1914)

\section{Personel temini}

Havacılık askeri bir unsur olarak teşkilatlanmaya başladığı zaman ilk havacılar, karacı ve denizci personelden oluşmuştur. Personel seçiminde bazı kriterler göz önünde bulundurulmuştur. Bunlar; deniz ve salıncaktan başları dönmeyen, cesur ve sebatkâr, piyade, topçu ve süvari sınıfına mensup, teknik ve motor bilgisine haiz, Fransızca ve Almanca bilen teğmen ve yüzbaşı rütbesinde subaylar olması istenmiştir (Kural 1974:22-26,41-44).

Savaş yıllarında bir uygulama ile astsubayların da pilot olması kararlaştırılmıştır. Bu kapsamda personel kaynağı güçlendirilmiştir. Üsteğmen Fethi örneğinde olduğu gibi makinistler önceleri subaylardan da seçilmiştir. Daha sonra ise astsubayların makinist olması uygulaması başlatılmıştır (Kansu 2006: 127, Kurter 2009: 107). Keza Teğmen Aziz de benzer eğitime tefrik edilmiştir (Keyüsk 1950: 39).

\section{Personel eğitimi}

İlk pilotlar, pilotaj eğitimi için yurtdışına gönderilmişlerdir. 1911 yılı başlarında Avrupa'ya tayyarecilik eğitimi için subay gönderilmesi kararı kesinlik kazanmıştır. 14 Şubat 1911 tarihinde Genelkurmay tarafından 1., 2. ve 3. 
Ordulara bir genelge gönderilerek Avrupa'da tayyarecilik eğitimine gönderilmek üzere genelgede belirtilen özelliklere uyan ikişer subay adayın isimlerinin bildirilmesi istenmiştir. Yapılan seçimler sonucunda pilot adaylarından Yüzbaşı Mehmet Fesa'nın Fransa'ya, Teğmen Yusuf Kenan'ın ise Almanyàya gönderilmesi planlanmaktaydı. Ancak her ikisi de Fransa'da eğitim almıştır (Kurter 2009: 46, Kural 1974: 2, 3). Kısa süre içerisinde Fransa ve İngiltere'ye gruplar halinde subaylar gönderilmiş ve pilotaj eğitimi almışlardır. İlk grup olarak 1912 yılı başlarında Fransa'da Bleriot Uçuş Okulunda eğitimini tamamlayan, Yüzbaşı Mehmet Fesa 780, Teğmen Yusuf Kenan ise 797 numaralı uçuş brövesinin sahibi olmuştur. Yetkililerin ilgilendiği konulardan biri de pilotaj eğitiminin Türkiye'de gerçekleştirilmesi olmuştur. Bu amaca yönelik olarak 03 Temmuz 1912 tarihinde bugün Hava Harp Okulunun bulunduğu bölgeye yakın bir yerde Yeşilköy İstanbul'da pilot yetiştiren Hava Okulunun temelleri atılmıştır. Rasıt seçiminde ise ordu sevk ve idare kabiliyeti öne çıkmaktaydı. Bu nedenle kurmaylar bu alanda daha başarılı olmuşlardır. İlk dönemlerde daha ziyade kurmay subaylar rasıt olarak görev almıştır (Keyüsk 1950: 91). Enver Paşa da Yarbay rütbesinde rasıt olarak bazı görevler yapmıştır.

\section{Uçak, balon ve teçhizat tedariki}

Havacılık bugün olduğu gibi ilk zamanlarda da oldukça pahalı bir sektör olması nedeni ile devletlerin bütçesini etkilemiştir. Osmanlı mali yapısı bundan olumsuz etkilemiştir. Havacılık alanında dönemin en önemli üç problemi; mali sıkıntı, sevk ve idarede başsızlık (müstakil ve kendi konseptine göre hareket eden bir hava unsurunun henüz şekillenmemiş olmasının sonucu), Avrupa'daki gelişmelerden habersiz olunması ve bilgi eksikliği olarak belirlenmiştir (Sarp 1986: 27-43, Keyüsk 1950: 158, Yalçın 2008: 20, 21).

İlk yıllarda uçaklardaki teknolojik gelişme oldukça hızlıydı. Zaman zaman aynı yıl içerisinde envantere giren uçağın envanterden çıktığı da oluyordu. 1912-1921 yılları arasında 61 tipte uçağın Osmanlı ordu envanterine girmesi bu kapsamdadır (Uçak Albümü 1912-2009: 1-60). Tabii ki bu yıllarda her yeni uçak, emniyet açısından da güçlendirilmekte olduğundan daha güvenilir olmaktaydı. Bu ise uçakların takibini zorunlu hale getirmekteydi.

Osmanlı İmparatorluğu yöneticileri teşkilatı oluşturma, pilot yetiştirme, Batı'da yaşanan gelişmeleri yakından izleme gibi önemli tedbirleri alırken, 
devletin mali sorunları sebebiyle uçak temininde güçlükler yaşanmıştır. Bu sürece, bağışlar ve moral desteği ile Osmanlı bürokrasisi ve halkı büyük destek vermiştir. Bazı varlıklı Türkler, tek başlarına uçak alıp Osmanlı ordusuna bağışlamışlardır. Sultan Mehmet Reşat, Kur. Yb. Süreyya Bey’in babası eski Serasker Rıza Paşa ve Mısır Prensi Celalettin bunlardan bazılarıdır. Mahmut Şevket Paşa 30 altın bağış ile maaşının 1/4’ünü altı ay süreyle bağışlar. Subaylar, polisler ve memurlar da destek çıkarlar. 1909 yılında kurularak Osmanlı Sultanının himayesinde çalışan Donanma Cemiyetinin havacılığa önemli maddi katkıları olmuştur (Yalçın 2004: 25-27, Yalçın-Gazi Akd. 2010: 194-196).

Kur. Yb. Süreyya Bey ve Bnb. Mehmet Ali Beylerden oluşan inceleme ekibi 07 Mayıs-05 Temmuz 1912 tarihleri arasında Avrupa gezisine çıkarlar. Bu havacılık alanında ilk tetkik gezisidir. Bu kapsamda; Almanya, Avusturya, Fransa ve kısmen İngiltere'yi gezerler (İlmen 1947: 38-100, 143-160, Kansu vd. 1971: 125, Kural 1974: 190-202, Kurter 2006: 92, Keyüsk 1950: 3139, Zekeriya 2015: 37-53). Avrupa'da kurulan uçak ve balon fabrikalarının büyük bir kısmı gezilmiş ve mukayesesi yapılmış, ihtiyaç duyulan teçhizat ve uçaklar sipariş edilmiştir. (İlmen 1947: 37-100, Kurter 2009: 92-102).

\section{Uçak fabrikası kurma çalışmaları}

Balkan Savaşları sonrası Osmanlı havacılığında uçak üretmeye yönelik bir gelişme olmuştur. Bir Macar şirketi, İstanbul'da uçak fabrikası yapmak için girişimlerde bulunmuş olmasına rağmen bu gerçekleşmeyen bir teşebbüs olarak kalmıştır (Kural 1974: 5,6). 1913 yılında üzerinde çalışlan ve hazırlanan taslak mutabakat zamanına göre, dikkate değer öngörülerde bulunmuştur. Bir uçuş okulu açılması, Türklerin de istihdamı ve buluşların gizli tutulması bunlardandır (Kural 1974: 5, 326, 327, Yalçın 2008: 26-28). İmza aşamasında İmalat-1 Harbiye Müdürlüğü̉ nün ilave görüşleri eklenmesi için olumlu sonuç beklenirken hazırlanan protokole; kimin, niçin yazdığ bilinmeyen, "Bu teklif kabul edilmemiş ve bu iş de yapılmamıştır." notu eklenmiş ve proje gerçekleşmemiştir (Kural 1974: 328).

Temmuz 1914 tarihinde İstanbul gazetelerinde bir başka girişim haberi yer almıştır. Hayri Bey ve Rıza Bey adlarında otomobil teknisyenliği bilgisi olan kişiler, Tophane askerî fabrikasına müracaat ederek uçak yapma arzularını dile getirmişlerdir. Bu kişilere müsaade edilmişse de işe imal edilen uçak 
uçurulamamış ve bu ikinci teşebbüs de yarım kalmıştır (Verel 1985: 40, Gökhan 1989: 54).

Birinci Dünya Savaşı'nın devam ettiği 1916 yılında iki Alman fabrikası Türkiye'de uçak üretiminin yapılabilirliği konusunda çalışmalar yapmışlardır. Sonuç olumsuz olmuştur (Flanagan: 41, 42, Yalçın 2008: 32).

\section{İcra edilen harekât görevleri}

Havacılık, Osmanlı İmparatorluğun son zamanlarında ortaya çıkan bir gelişmedir. Osmanlı bu yeni gelişmeye ilgi göstermiştir. Henüz kurulan Türk askeri havacılığı kısa zamanda birçok savaşa katılmıştır. Bunun yanında diğer bazı harekât görevleri de yapmıştır. Çalışmada bunlar kısaca incelenmiştir.

Trablusgarp Savaşı (Türk-Ittalyan Harbi)'nde Türk Askeri Havacılı̆̆ı (29.09.1911-18.10.1912)

360 yıldır Türk toprağı olan Trablusgarp'ın, İtalya tarafından işgal girişimi ile gerçekleşen savaştır. Bu savaş ile İmparatorluk, bugünkü Libya ile Batı Anadolu kıyılarında yer alan 12 Adaları kaybetmiştir. Savaşta, birliklerin ve yerli halktan toplanan gönüllülerin komutanlığını yürüten Neşet Bey, uçağa olan ihtiyacı sıklıkla bildirmiştir.

Osmanlı Devleti karadan ve denizden ulaşamadığı bu vatan parçasına hiç olmazsa havadan destek olabilmek için girişimler yapmaya başlamıştı. Henüz Türk pilotu olmadığından, Fransa’da bulunan Osmanlı heyetinin girişimi ile iki Fransız pilot ile sözleşme yapılmıştır. İki uçak temin edilmiş ve bu uçakları kullanmak için sözleşme yapılan Fransız pilotlar, Güney Cezayir'deki Biskra’dan ileriye geçmek istememişlerdir. Buraya kadar getirilen uçaklara Fransa el koymuştur (Kansu vd. 1971: 121, Keyüsk 1950: 31, Yalçın 2009: 13). İtalyanlar, bir savaşta ilk uçak kullanan ülke olmuştur. 28 uçak ve dört balona sahiptiler. 22 Ekim 1911 tarihinde Plt. Yzb. Carlo Piazza, Blériot XI tipi uçağı ile Türk hatları üzerinde keşif uçuşu yapmıştır. Türk birlikleri ise İtalyan uçaklarına sırt üstü yatarak toplu olarak ateşle karşılık vermiştir. Yoğun yer ateşine maruz kalan İtalyanlar daha yüksekten uçmak zorunda kalmıştır. Örneğin 31 Ocak 1912'de Pilot Carlo, uçağına yerden açılan ateş sonrası isabet alması sonucu zaruri iniş yapmış ve uçağı ile birlikte esir alınmıştır. Uçakların savaşta önemi ortaya çıkmaya başlamıştır (Yalçın 2009: 13, Kansu vd. 1971: 121-124). İtalyan uçaklara yerden ateş açma, tarihte icra edilmiş ilk hava savunma görevidir. Trablusgarp Savaşı; uçak kullanma, 
esir alma, pilot öldürme, hava savunma görevi, havadan keşif yapma, bildiri atma ve bombalama gibi birçok uygulaması ile dünya havacılık tarihinde ilklerin gerçekleştiği bir savaştır.

\section{Balkan Savaşlarında Türk Askeri Hava Gücü (08.10.1912-14.11.1913)}

Balkan Savaşlarında Türklerin iki Deperdussin, bir Bleriot, üç REP, 2 Bristol, iki Harlan uçağı bulunmaktaydı. Savaşın devam ettiği süre içinde ise bir Bleriot, iki Mars, bir Deperdussin, üç REP uçağının daha tedariki yapılmıştır. Süreyya Bey tarafından sipariş edilen iki Bristol uçağı belirtilen tarihe yetişemediğinden iptal edilmiş, yedinci R.E.P. uçağına ise sevki esnasında Sırplar tarafından el konmuştur. Savaşta kullanılabilecek uçak sayısı 10 adetti. Balkan devletlerinin uçak durumu şöyleydi: Bulgarların 10, Sırpların 5-6, Yunanlıların altı uçağı bulunuyordu. Bu uçaklardan üç adedi Amerikalı Rumlar tarafindan hediye edilmiştir (Nikolojsen 2005: 7, Kural 1974: 115, Kansu vd. 1971: 129, Aydar 1948: 37, Yalçın 2009: 15). Balkan ülkelerine kendi pilotları dışında başta Fransız ve Rus pilotları ile teknisyenleri yardımcı olmuşlardır. Tarafların hava güçleri karşılaştırıldığında Osmanlı İmparatorluğu'nun imkânlarının daha sınırlı olduğu anlaşılmaktadır (Keyüsk 1950: 76-78, Kansu vd. 1971: 129, 130; Taşdemir 2013: 933).

Balkan Savaşları başladığı tarihte Türk Ordusunda 16 pilot bulunuyordu. Bu pilotlar arasında; Fesa, Fethi, Nuri, Fazıl, Salim Beyler gibi isimler öne çımaktaydı (Keyüsk 1950: 88). Pilotların büyük çoğunluğu uçuş eğitimini tam olarak tamamlayamadığından uçuşa elverişli değillerdi. Uçuşa hazır olan Türk pilot sayısı 6'dır. Pilot açığını kapatmak için Fransa'dan üç pilot, üç makinist ile Almanya'dan dört Alman pilot ve iki makinist görevlendirilmiştir (Kansu vd. 1971: 129, Kural 1974: 115, Taşdemir 2013: 937). Harekâtın birinci aşamasında iklim koşulları ve ani gelişen düşman ilerleyişi karşısında Osmanlı şark ordusu, uçaklardan istifade edememiştir. Geri çekilme zorunluluğu ortaya çıkınca uçaklar, Bulgarların eline geçmemesi için yakılmışırı.

Osmanlı Garp ordusunda uçaklar keşif maksadıyla etkin olarak kullanılmıştır. Yunan ordusunun Selanik’e yaklaşması ile geri çekilme başlamış ve buradaki iki uçak Yunanların eline geçmemesi için yakılmış, pilotlar ele geçmemek için uygun yerlerde saklanmışır.

Bulgarlar ise Edirne üzerinde sık sık uçmuşlar ve sabit balon kullanmışlardır. 
Bulgar havacılar, Selimiye Camii'ni de bombalamışlardır. Uçaklar ile beyanname atma, bombalama ve keşif görevi yapmışlardır. 03 Aralık 1913'de imzalanan ateşkes ile savaşın birinci devresi bitmiştir (Kansu vd. 1971: 132, 138, Keyüsk 1950: 99).

Harekâtın ikinci evresinde pilot olarak Fesa, Nuri, Salim, Fethi, Fazıl, Mithat Nuri, Refik ve Fevzi görev yapacak durumdadır. Fethi ve Salim Beyler Çatalca üzerinde birkaç uçuş yapmışlardır.

Balkan Savaşlarının ikinci safhası, Türk hava gücünün kendi imkân ve kabiliyeti ile harekât yaptığı ilk savaş olmuştur. Yalnız savaş sonunda sekiz (8) uçağını düşman eline geçmemesi için tahrip etmiş, bir uçağa ise savaş başlamadan Sırbistan el koymuş olduğundan dokuz (9) uçağını kaybetmiştir. Türk pilotların dünyanın en deneyimli pilotları oldukları birçok yabancı tarafından da teyit edilmiştir (Kurter 2009: 179). Ecnebi pilotlar Balkan devletleri hava unsurlarında bir haçlı askeri ruhaniyeti ile uçarken, Osmanlı ordusundaki yabancılar verimli uçmamış ve kayda değer bir katkıları olmamıştır (Keyüsk 1950: 94, 95).

\section{Türk havacılığını geliştirme programları}

Balkan Harbi sonrası dönemde Osmanlı ordusunun modernize edilmesi için bir çalışma başlatılmıştır. 1914 yılı başlarında Bnb. Veli Bey başkanlığında bir heyet tarafından Avrupa'da havacılık alanında meydana gelen gelişmeleri izlemek maksadıyla bir gezi yapılır. Türk ekibi bu gezide, Fransa’da 22 uçak fabrikasını incelemiştir (Kurter 2009: 211, Kansu vd. 1971: 158). Heyete Fransa'da, Hava Binbaşı Marki De Goys de Mazeyraç Osmanlı havacılığında görevlendirilmesi önerilmiştir. De Goys, 04 Mayıs 1914 tarihinde İstanbul'a gelmiş ve seferberliğin ilan edildiği 1914 yılı Ağustos ayı başına kadar Yeşilköy Hava Okulu Müdürü olarak görev yapmıştır. Görev yaptığı süre içinde hava personelinin kıyafetlerinde birtakım değişiklikler yapmıştır. Kalpak üzerine ay yıldızlı kanat takılmıştır. Üniformanın yakası ve pantolon zırhı kırmızı renk olarak belirlenmiştir (Kurter 2009: 215-218). Haziran 1914 'te kurulan ikinci heyet 35 kara, 15 deniz uçağını sipariş etmiştir. Ancak gelişen olaylar bu siparişlerin teslimine firsat vermemiş, Fransa' ya sipariş edilen 15 adet Nieuport uçağı daha sonra Kanal Cephesi'nde Türklere karşı kullanılmıştır (Kurter 2009: 159, Kansu vd. 1971: 159, 176). İngilizlerin 
Türk savaş gemilerini vermemesi hadisesinin hava boyutu da Fransızlar tarafından uygulanmıştır.

\section{Türk Havacıların İlk Uzun Mesafeli Uçuşları}

Balkan Savaşları sonrası Türk havacıları ilk uzun hava seyrüseferini yapmışlardır. Plt.Ütğm. Nuri Bey, Prens Celalettin isimli Deperdussin tipi uçakla rasıt olarak Tğm. Hami ile birlikte Edirne'den 24 Ekim 1913 tarihinde kalkarak Babaeski-Çorlu-Çatalca üzerinden Yeşilköy’e gelmiştir. 3 saat 5 dakika süren bu ilk uzun uçuş 10 altınla mükâfatlandırılmıştır. Bu dönemde Plt.Yzb. Salim ve rasıtı Kur.Yzb. Kemal, Bleriot tipi uçakla Kırklareli’nden Yeşilköy’e dönerken yanlışlıkla Marmara'yı aşıp Manyas'a inmişlerdir. 30 Ekim 1913'de ise Marmara bilinerek 2'nci defa geçilmiş̧ir (Kansu vd. 1971: 140, Kurter 2009: 183-185).

\section{Kıtalararası Osmanlı hava seferi (İstanbul-Kahire Seferi)}

Osmanlı İmparatorluğu’nun Balkan Savaşlarından ağır bir yenilgi alması halk üzerinde olumsuz bir etkisi bırakmışır. Halkın moral ve motivasyonunu artırmak ve devlete olan itimatlarını pekiştirmek için bir hava seferi düzenlenmesine karar verilmiştir.

Hava seferi, 14 meydana iniş ve kalkışşeklinde planmış olup en kısa mesafe Beyrut-Şam arası $90 \mathrm{~km}$, en uzun mesafe ise $300 \mathrm{~km}$ mesafeli Humus-Beyrut arası uçuş olacak şekilde planlanmıştır (Aydar 1947: 6-8). Seferin rotası; İstanbul, Eskişehir, Afyon, Konya, Ulukışla, Adana, Halep, Humus, Beyrut, Şam, Kudüs, El-Ariş, Port Said, Kahire ve İskenderiye olarak planlanmıştır (Yalçın MJH 2014: 330). Uçuş süresinin saatte yaklaşık 100 kilometre (ortalama 54 knot/saat sürat) ile 25 saat süreceği öngörülmüştür (İlkler 2007: 7, Uçantürk 1974: 79, Ufukların Ötesindekiler: 19). Uçuş için milletin bağışları ile alınan "Muavenet-i Milliye" isimli "Bleriot" tipi uçakla Pilot Yzb. Fethi ve Rasıt Ütğm. Sadık "Prens Celalettin” isimli" Deperdussin” tipi uçakla Edirne-İstanbul arası ilk uzun mesafe uçuşunu gerçekleştiren (Uçantürk 1974: 79). Plt. Ütğm. Nuri Bey ve Rasıt Yzb. İsmail Hakkı Bey’in uçması planlanır. Uçuşun toplam mesafesi $2.515 \mathrm{~km}$.'dir (Turgut 1955: 11, Yalçın 2009: 17-22, Yalçın MJH 2014: 328-348). 


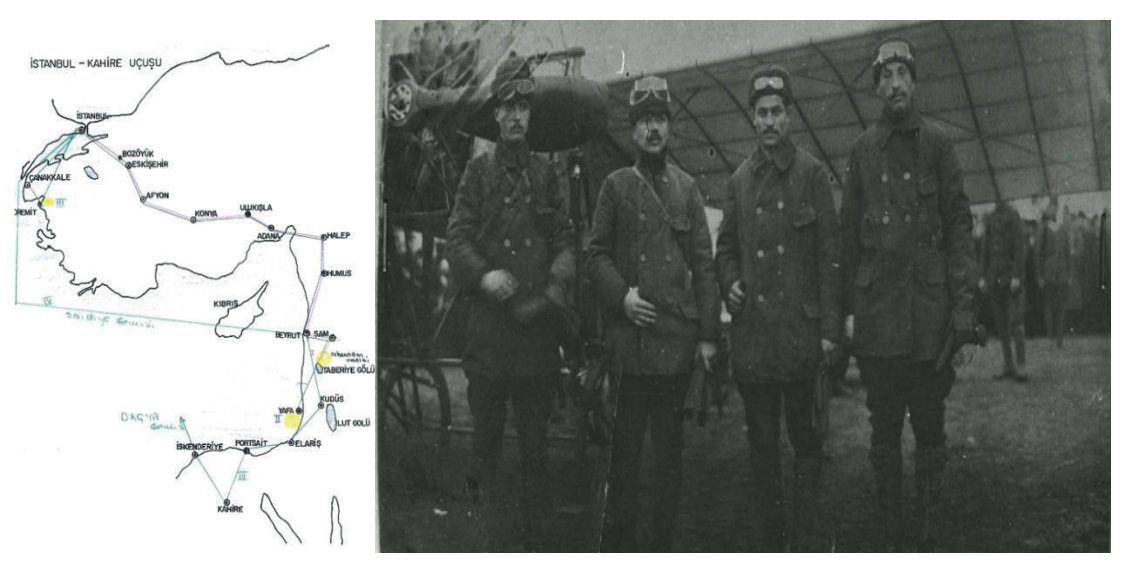

Resim 8. Kitalararası Osmanlı Hava Seferinin Mürettebatı ve Güzergâh haritast: (08.02.1914-22.05.1914) (Soldan Sağa: Sadık, İsmail Hakkı, Fethi ve Nuri Beyler)

08 Şubat 1914'te İstanbul Yeşilköy'de yapılan devlet töreninin ardından saat 09.10'da Nuri Bey'in kullandığ 1 "Prens Celalettin", 09.12'de Plt. Yzb. Fethi'nin kullandığı "Muavenet-i Milliye" havalanır. 27 Şubat 1914 tarihinde Yzb. Fethi Bey ile rasıtı Yzb. Sadık Bey'ler, "Muaveneti Milliye" isimli Bleriot tipi uçakla Şam'dan Kudüs yönüne havalanırlar ve Taberiye Gölü’nün güney doğusunda bulunan "Küfrüharib” kayalığına düşerler. Yzb. Fethi Bey ile rasıtı Yzb. Sadık Bey'ler yolculuğu tamamlayamadan şehit olurlar (Türklerin Havacılĭga Hizmetleri 1982: 23, Keyüsk 1950: 186-194, Sözeri 1961: 42, Yalçın 2009: 19, Ünalp 2011: 139). Seyahat, Fethi Bey için uçağın düşmesine kadar ciddi bir sorun olmazken, Nuri Beyin uçağı birçok sorunla karşılaşmıştır (Yalçın MJH 2014: 331). Fethi ve Sadık Bey’lerin cenazesi 28 Şubat 1914'te Şam'da Emeviye Camii'ndeki Selahaddin Eyyübi türbesinin avlusuna defnedilir. Uçağın enkazı İstanbul'da askeri müzeye konulur (Kansu vd. 1971: 154, Kurter 2009: 202-204). Asıl adı Megri (Makri) olan ilçe adına izafeten Fethiye adını alır. Behçet Kemal Çağlar’ın şiirinde yer alır:

Arslan uçtu diye söylenir methi

Bu kutsal topră̆ın çocuğu Fethi,

Bak "Fethiye" oldu sayende, Megri,

Arslanım gölgende hürdür vatanın. (www.tayyareci.com) 


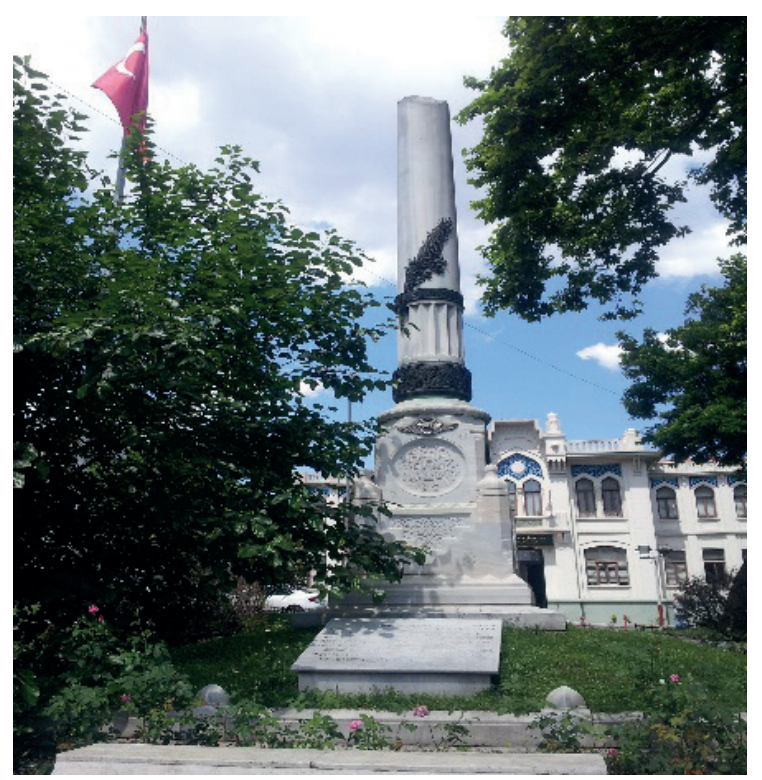

Resim 9. Seferin Anısına Yapılan Anıt-İstanbul Fatih Semti

11 Mart 1914 tarihinde, binlerce insan Yafádaki alanda toplanmış ve Nuri Bey'in uçuşunu görmek istemektedir. Rüzgâr kalkış istikametine doğru olarak esmektedir, bu durumda kalkış yapılmaması gerektiği halde, yaşanılan süreçte yüklenilen aşırı stres ile uçuşa karar verilir. Uçak takat kaybeder ve denize düşer. Nuri Bey, yüzerek kıyıya doğru ilerler ancak kıyafetinin ağırlığı ile boğulur. Rasıt Yzb. İsmail Hakkı Bey ise yüzme bilmediğinden henüz batmamış olan uçakta kalır ve olaydan sonra bölgeye gelenler tarafından kurtarilır (Aydar 1948: 48, Gediz: 82, Sarp 1986: 39, Kurter 2009: 207, 208, Kocatürk 2013:160-165, Ünalp 2011: 134). Yzb. İsmail Hakkı Bey Birinci Dünya Savaşı yıllarında İran taraflarında şehit düşmüştür.

Seferin tamamlanması için planlanan "Ertuğrul” isimli üçüncü uçak, Rasit Yzb. Kemal Bey ve Plt.Yzb. Salim (İlkuçan)'den oluşan bir ekiple fark$l_{1}$ bir rota takip ederek Çanakkale ve Edremit halkının isteği ile Edremit üzerinden devam eder (Kural1974:VIII, Kansu vd.1971:155). Üçüncü ekip gönüllülük esasına göre bu göreve katılmıştır (Gediz84). Uçak, Kemerdere'de bir kırım geçirir. Arıza giderilerek 13 Mart'ta Edremit'e doğru tekrar havalanır, hava muhalefeti nedeniyle bu kez de Küçükkuyu yakınında ormanlık bir alanda ağaç üzerine düşerler. Halk olay mahalline gelerek uçuş 
ekibini kurtarır (Aydar1938:1550, Aydar1948:94,95). Bu durum üzerine Edremitliler yeni bir Bleriot tipi uçak satın alırlar ve uçağa "Edremit" adı verilir. Bu, seferin 4’üncü uçağıdır. Seferin 4’üncü uçağı Edremit tayyaresi 07 Nisan 1914’te İstanbul'a gelmiştir. 11 Nisan 1914 tarihinde Hidivviye Kumpanyasına (şirketi) ait Saidiye gemisiyle uçak, mürettebat ve makinistler Beyrut'a hareket etmişlerdir. 19 Nisan'da Beyrut'ta montaj yapılmış ve antremanlara başlanmıştır. 01 Mayıs 1914'te Kudüs'e gelinmiştir (Kansu vd.1971:155,Özdemir 1981:83). Takiben El Ariş, Port-Said'e uçulmuştur (Şehbal1914:23). Mısırlı Rumlar üçüncü ekibin uçağının yeniden kırıma uğradığı dedikodusunu çıkardıkları bir zamanda "Edremit" uçağı 09 Mayıs 1914'te Kahire'ye gelmiştir (Yalçın2009:21).

Yaşanan talihsiz kazalardan sonra, basında da heyetin güzergâh ve faaliyeti titizlikle takip edilmiştir (Tasvir-i Efkar 13 Nisan 1914, Tasvir-i Efkar 6 Mayıs 1914). Uçak Kahire, Tanta ve İskenderiye'de uçuşlar ve birçok gösteriler yapmıştır. Gösteriye sayıları yüz binleri aşan Mısırlı katılmıştır. Mısırlıların Türklere yönelik yoğun sempatisi İngiliz görevlileri ciddi olarak rahatsız etmiştir. Türk pilotun anılarına göre uçağını düşürmeye yönelik suikast teşebbüsünde bulunmuşlardır (Yalçın MJH 2014: 339).

Heyet 15 Mayıs'da Tanta'ya gelmiş, 22 Mayıs 1914 tarihinde Romanya'nın Daçya Vapuru ile İstanbul'a dönülmüştür (Yalçın MJH 2014: 332).

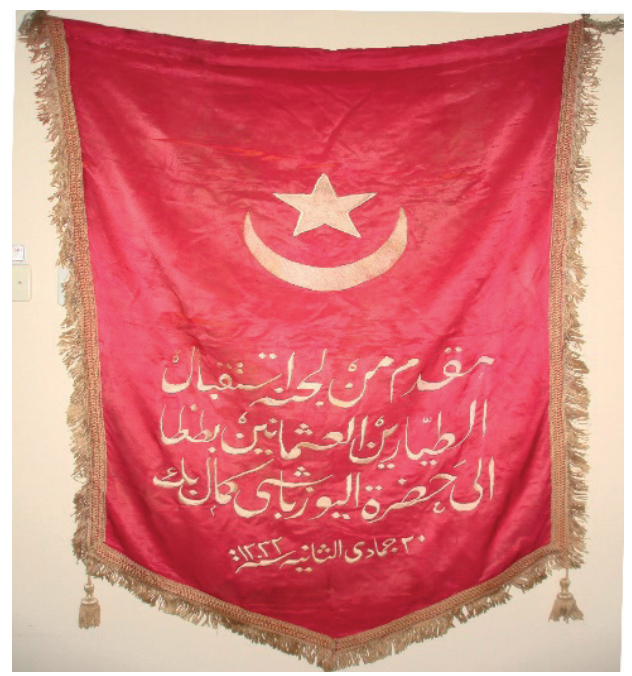

Resim 10. Tanta Objesi (Yeşilköy Hava Müze K.lığı-2015) 
İstanbul-Kahire seferi; en yetenekli ve tecrübeli pilotlar ile uçakların kaybedilmesine (Yalçın MJH 2014: 343) rağmen kararlılıkla sonuçlandırılmıştır. Bu seferin istihbari amacı da olduğu tartışılmaktadır (Ünalp 2011: 134). Nuri Bey’in, Teşkilat-ı Mahsusa’da görev aldığına dair bilgiler bulunmaktadır. Bu projede yaşananlar kurum kültürünün oluşmasına katkı sağlamıştır. Günümüzde bir Suriyeli Tarih Profesörü konuyu, "Şam’a iniş yapan ilk uçak" diye anmaktadır (Kasmieh 2011: 130).

\section{Birinci Dünya Savaşında Türk askeri hava gücü}

1912-1914 tarihleri arasında envantere toplamda 25 uçak girmiştir. Daha önce de ifade edildiği gibi Fransa’ya sipariş verilmesine rağmen 50 uçak gelişen siyasi olaylar ve harp şartları nedeniyle teslim edilmemiştir (Nikolajsen 2005: 7-9). 1914 yılında savaşın başladığı tarih esas alınsa bile henüz üç yıllık bir geçmişi olan hava kuvvetlerinin karşılaşacağı güçlükler açıktır. İmparatorluk havacılığı kısa zaman içerisinde birçok olumsuz gelişmeye rağmen Birinci Dünya Savaşı yıllarında gelişmesini devam ettirmiştir.

Osmanlı İmparatorluğu savaşa girerken; üçü faal, ikisi gayri faal, beş kara uçağı ile iki deniz tayyaresi toplam yedi adet uçağı bulunuyordu. Eğitim uçakları ile bu sayı 12 uçağa çıkıyordu. Bununla birlikte işe yarar uçak sayısı ise yalnız altı adettir. Osmanlı havacılıkta müttefiklerine muhtaçtı. 1915'de 40, takip eden 1916, 1917 ve 1918 yıllarında uçak sayısı 100’lü sayıya ulaşmıştır. Savaşa başlarken 10 kadar pilotu olan Osmanlı havacılığının insan gücü de biraz gelişmiştir. Yine savaş yıllarında, Osmanlı hava gücünün 100 kadar pilot ve rasıdı olmuştur. Savaşın başladığı zamanlarda Türk hava birliklerinin ağırlı̆̆ı Yeşilköy’deydi. İki uçak İzmir'e, bir uçak Çanakkale’ye olmak üzere üç tayyare gönderilmiştir; ancak bu uçaklar bir etkinlik gösterememiş, her defasında hafif veya ağır kırım geçirerek maddi kayıplara sebep olduklarından geri çağrılmışlardır. Osmanlı İmparatorluğu’nun bu tarihte yüz ölçümünün 6,5 milyon kilometre kare olduğu dikkate alındığında yetersiz kaldığı açıktır. Osmanlı orduları savaş süresince; Çanakkale, Irak, Filistin, Arabistan, Kafkas, Makedonya, Galiçya, Romanya cephelerinde savaşmıştır.

Filistin Cephesi ilk zamanlar hava faaliyeti bakımından sakindi. Almanların Paşa Tayyare Bölükleri gelinceye kadar, Türkler buraya yeterli uçak gönderememiştir. Bunun üzerine ele geçirilen İngiliz uçakları ile bir hava filosu oluş- 
turulmuş ve Plt. Ütğm. Fazıl Beyin gayretleriyle bu uçaklar İngilizlere karşı başarılı bir şekilde kullanılmıştır (Kayabalı-Cemender 1972: 496, Özdemir 1981: 120-127). Savaş yıllarında Türk hava teşkilatı gün be gün gelişme göstermekteydi. Örneğin 1915 yllına ait bir hava birliğinde 17/13 zabitan, 25/21 küçük zabitan ile 61/57 erat, 35-40 binek ve koşum hayvanı, 2 otomobil bulunuyordu (ATASE Arşivi, BDH, Klasör: 1392, Dosya: 19, Belge: 003-02). İki takımdan oluşan her tayyare bölüğünde uçak sayısı değişmekle birlikte 4-6 civarındaydı.

Gazze savaşlarının yapıldığı bir dönemde bölgede bulunan seyyah ve gazeteci Lowwel Thomas'in İngiliz Hava Binbaşı Kenneth Brown Collins'ten aktardığı anekdot:

... İki Halberstadta’a karşı havada 25 tayyaremiz olduğu halde, Türkler rasıtlarımızdan birini öldürdü. İki pilotumuzu yaraladı ve iki tayyaremizi de kurşunla yere düşürdü. Diğer altısını öyle zarara uğrattılar ki bunlar ancak yere varabildiler. ...Gazzede bize duman attıran o iki tayyareci ile ... hakkıyla övünebilirler. (Kansu vd. 1971:140, Haber Gazetesi 1936: Son Ehli Salip Muh.)

General Von Kress anılarında, Filistin Cephesinde ilk dönemlerde bile en önemli sıkıntının düşman uçakları ile suya ulaşamama olduğunu belirtmektedir (Von Kress 2007: 98, 99). 1917 yılından itibaren Amerikalıların savaşa girmesi ile İngiltere, Filistin Cephesine ağıllık vermiş ve buraya büyük hava gücü göndermiştir. Buradaki yoğun hava gücünün tahribatı, Türklerin imparatorluğunu kaybetmesine neden olmuştur.

İngilizler savaş süresince İstanbul'a yönelik filolar halinde saldırılar düzenlemişlerdir. Osmanlı yönetimi bu durumu defaten protesto etmişse de etkili olmamıştır. 25 Ekim1918'de Yüzbaşı Fazıl Bey’in 5 İngiliz uçağına karşı İstanbul semalarında hava muharebesi yapmıştır. Bu hadise Türklerin Birinci Dünya Savaşı'nda, sınırları içindeki son hava muharebesidir. Hava kuvvetleri sayısal olarak savaş sonunda 17 tayyare, 3 deniz hava ile ilaveten üç Türk balon bölügü olmak üzere yapılanmış durumdaydı (Flanagan: 91, Kansu vd. 1971: 167, 171, Kayabalı-Cemender 1972: 494, 495, Yılmaz 2003: 175). Müfrezelerle sayı daha yüksektir.

Savaşın sona ermesiyle Osmanlı havacıları Anadolu’ya çekilmişlerdir. Filistin Cephesi bakiyeleri Konya, Irak Cephesi bakiyeleri ise Elazığda bulunan 
hava birliklerinde konuşlanır. Ne var ki havacılık genelde Almanlara havale edildiğinden Almanların ülkelerine dönmesiyle teşkilat olarak oldukça büyük, gerçekte ise varllğı kaybolan bir kuvvet seviyesindedir (Göymen 1964: 122-125). İşgalci güçler İstanbul'da bulunan Türk havacıları kontrol altında tutmaya çalısırıken, Türk havacıllğının doğduğu yer olan Yeşilköy’ü işgal etmişlerdir. İsgal dönemlerinde Türk Hava Kuvvetlerine ait birçok malzeme izinsiz alınmış veya gasp olayları gerçekleşmiştir. Örneğin 21 Kasım 1919 tarihli bir yazıda Fransız Nişancı Alayı Birinci Taburuna teslim edilen eşya ile Topçu Endaht Mektebine ait barakaların tahliyesinde makbuz verilmesinin İngilizler tarafından alınan eşyanın cetvelinin listesi verilmektedir (ATASE, ISH, Kutu: 24, Gömlek: 71, Belge:11). Ayastefanos Tayyare İstasyonuna ait büyük kamyonun örtüsünü alan Fransızlardan örtünün geri istendiğine dair bilgiler yer almaktadır (ATASE, ISH, Kutu: 69, Gömlek:117, Belge:1). Yine İtilaf güçlerinin birçok eylemleri yazışmalara konu olmuştur. Örneğin, Sahra Köyü’nde bulunan Ayastefanos Tayyare İstasyonu ile burada Umur-u Havaiye deposundaki; ot, saman, kereste ve sair eşyanın Fransızlarca yağmalandığı ve izinsiz kullanıldığı bilgisi arşiv belgelerinde yer almaktadır (ATASE, ISH, Kutu: 69, Gömlek:115, Belge:8). Takiben Osmanlı havcıları Maltepe tarafinda konuşlanmak durumunda kalmıştır. Gelişmeler üzerine bu durumdan ciddi rahatsızlık duyan havacılar ise bir plan dâhilinde Anadolu'ya geçerek Mustafa Kemal Paşa'nın ordusunda yer almışlardır. Bir hava uzmanı Binbaşı Orthlieb; "Bu savaşın gerçek hava mucizesi, keşiflerdeki başarılar olmuştur.” (Kansu vd. 1971: 351) der. Hava kuvvetleri bu süreçte kara unsurlarının işini oldukça kolaylaştırmıştır.

\section{Almanlarla İş Birliği ve Türk Havacılığına Tesirleri}

Osmanlı İmparatorluğu’nun Almanya ile 02 Ağustos 1914 tarihinde ittifak yapması sonucu Fransız Binbaşı De Goys, ülkeden ayrılırken, Osmanlı Havacılığı üzerinde Alman etkisi başlamıştır. Kuruluş yıllarında Fransa’dan teknik destek alınırken Birinci Dünya Savaşı yıllarında Almanya savaş süresince Osmanlı havacılığını destekledi (Yalçın Ask. Tarih 2012:72). Şüphesiz bu destek yeterli değildi. Yaklaşık 48.000 uçak üretiminden Türklere verilen uçak sayısı Tayyare Paşa Bölükleri dahil 450 civarındadır. Kredi verilemediği durumlarda ise uçakların temininde önemli sorunlar yaşanmıştır.

03 Şubat 1915'de Alman Hava Pilot Üsteğmen Erich Serno İstanbul'a gelmiş ve Yüzbaşı rütbesi ile göreve başlamıştır. Serno, kısa bir süre Batı Cephe- 
si görevi dışında dört yıl Türkiye’de görev yapmış ve tümen seviyesi müstakil hava kuvvetlerinin komutanlığı görevini icra ettiği bir zamanda, binbaşı rütbesinde ülkesine dönmüştür.

1915 yılı içerisinde Almanya'dan uçakların gelmesi ile 10 hava birliği teşkil edilmiştir. Yine 1915 yılbaşlarından Ekim ayına kadar, Almanyadan verilmesi kabul edilen uçakların tesliminde, Bulgaristan henüz savaşa girmediğinden, doğrudan irtibat olmaması sebebiyle güçlükler yaşanmıştır. Uçaklara flatör (tekerlek) takılarak uzun mesafe uçulmasıyla bu sorun çözülmeye çalışılmıştır. Bu yöntemin de bir inovasyon olduğunu belirtmek gerekir.

Savaş süresince yalnız Türklerden oluşan, Türkler ve Almanların ortak görev aldıkları ya da Paşa Tayyare Bölükleri gibi yalnız Almanlardan oluşan bölükler mevcuttur. Ayrıca balon birliği de savaşın sonuna kadar varlığını sürdürmüştür. Almanya, parası peşin ödenmediği için zaman zaman acil ihtiyaç olmasına rağmen uçakları göndermemiştir.

Birinci Dünya Savaşı süresince; Türkiye'de görev yapan toplam Alman personel sayısı 295 uçucu subay, 95 uçucu astsubay, 1.740 teknik personelden oluşmaktadır (Flanagan: 91). Osmanlı kara ve hava unsuru savaş süresince 232 itilaf gücüne ait uçağı düşürmüş ya da indirmeye zorlamıştır.

Savaşın sona ermesi ve Osmanlı İmparatorluğunun savaştan mağlup olarak çekilmesi ile teşkilat sık olarak değişmiştir. Ordunun her biriminde olduğu gibi hava teşkilatında da küçülmeye gidilmiştir. Arşiv belgesinde de yer aldığı üzere, memleket ve ordunun mevcut durumu tasarruf icap ettirdiğinden ileride icabına bakılmak üzere Kuvay-1 Havaiye Müfettişliğinin Kuvay-1 Havaiye Şubesine çevrilmiştir (ATASE, ISH, Kutu:179, Gömlek:30, Belge: 1). Takiben 25 Haziran 1920 tarihinde ise Osmanlı Hava Kuvveti lağv edilmiştir. Sevr Antlaşmasına göre Yeşilköy’de Birinci Sınıf, İzmir, Konya ve Erzurum'da 2'nci sınıf tayyare istasyonları kurulması planlanmıştır. Yine buralarda ikişer uçaklı tayyare bölükleri teşkili öngörülmektedir (Kaymaklı 1997: 22).

\section{Milli Mücadele Dönemi Türk Havacılığı (19.05.1919-22.9.1922)}

1920 Mayıs'ında, doğudaki hava teşkilatında değişiklikler yapılmıştır. 7 ve 8. bölükler, 15. Kolordu kumandanlığının 27 Mayıs 1920 tarihli emriyle lağvedilmiş, yerine 15. Uçak Bölüğü teşkil edilmiştir. Türk askerî hava gücü, Millî Hükûmet'in teşkilatta yaptığı ilk ilavelerdendir. Millî Savunma 
Bakanlığı'nın 13 Haziran 1920 tarih ve 328 sayılı emri ile Ankara Hükûmeti'nin Hava Kuvvetleri teşkilatı kurulmuştur. Millî Savunma Bakanlığı Harbiye Dairesi; Yeşilköy Hava istasyonu ve diğer hava istasyonlarının belirsizliği karşısında tedbir almak zorundaydı. Milli Mücadele yıllarında Batı Cephesi’nde Birinci ve İkinci Hava Bölükleri teşkil edilmiştir. Resmi adı 2. Uçak Bölüğü olmasına rağmen Bölük Komutanı Plt. Yzb. Mehmet Fazıl'ın uçak gövdesinin iki yanına pençelerinde bomba taşıyan uçar vaziyette kartal resmi yaptırmasından dolayı, "Kartal Müfrezesi" adı verilmiştir (Ersoy 2001: 11, Tanman 1953: 51, Kavuncu 2002: 20, Özdemir 1981: 31, Candaş: 31). Birinci Dünya Savaşı sonunda Yunanların elinde 72 uçak bulunuyordu (Kaymaklı 1997: 41). Savaş süresince aldıkları İngiliz desteği de göz önüne alındığında hava gücü olarak oldukça sayısal yeterliliğe sahip oldukları ve envanterlerinde yüzün üzerinde uçak olacağı açıktır.

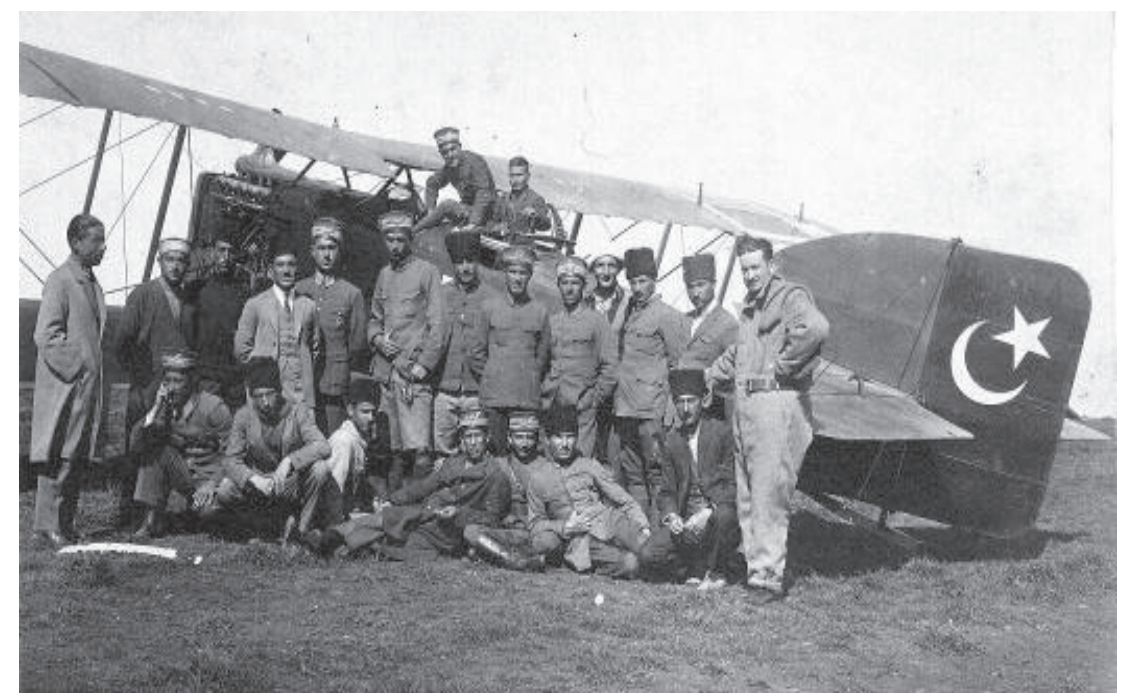

Resim 11. İstiklal Savaşı̇nda Türk Havacılar

Oysa Türkler pek çok defa Cephede tek uçağa kalmışlar hatta bazen bu da mümkün olmamıştır. Batı Cephesi Komutanı İsmet İnönü’nün 14 Mart 1921 tarihli mesajında "İnönü Meydan Muharebesi muzafferiyetinin amillerine; havacılarına hassaten selam ve teşekkür ederim...." ifadeleri bu zor şartları yansıtmaktadır. Yzb. Fazıl Bey’in, 21 Haziran 1921'de Kütahya semalarında tek başına yedi Yunan uçağına karşı hava muharebesine çıkışı ile Sakarya Meydan Savaşında 50 yunan uçağına karşı iki uçak gücüne sahip 
olmak da yine bu kapsamdadır. (Kaymaklı 1997: 57, 64, 73). Türk hava unsurları; keşif, bombardıman, hava-hava görevi başta olmak üzere dönemin hava harekât nevilerini başarı ile icra etmiştir. Milli Mücadele süresince Türkler üç, Yunanlar 25 uçak kaybetmişlerdir. Ganimet olarak Türklere oldukça yüksek miktarda uçak ve uçak malzemeleri ile mühimmat kalmıştır.

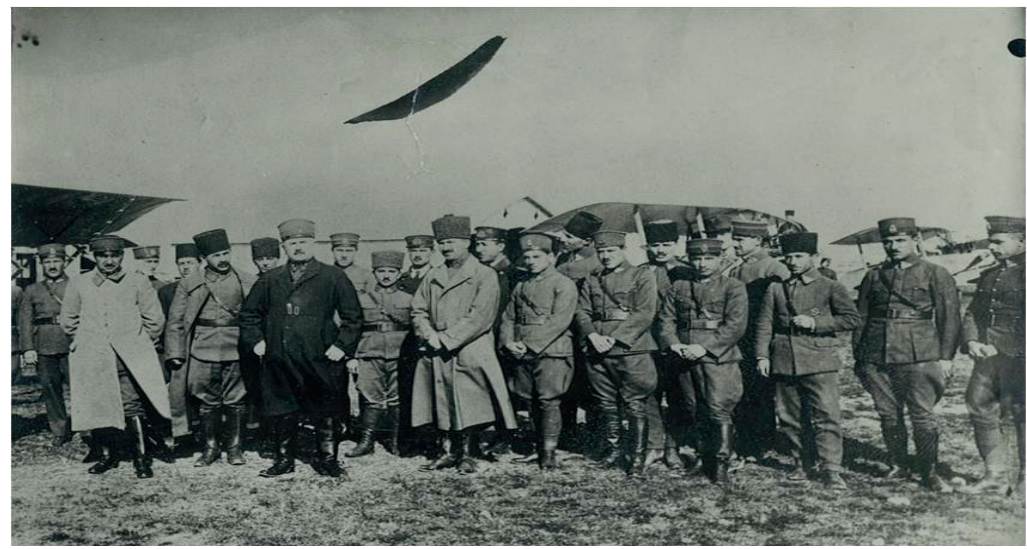

Resim 12. Ordu Müfettişi General Kazım Karabekir Seydiköyde Hava Birliklerini Teftiş Ediyor

\section{Sonuç}

Türk havacılı̆̆ının kuruluş yıllarında en önemli sorun; gelişebilmesi ve kendi imkânları ile yükselebilmesi için gereken bir barış dönemine sahip olmamasıdır. Mali kıskaç ve savaşlar öngörülü liderlerin projelerine büyük güçlükler çıkarmıştır. Alan Palmer, Osmanlı ordusunun 1911-1912 şartlarında beş altı yıllık bir barış süresinde kalsaydı yeniden dayanılmaz bir güç hâline gelebileceği değerlendirmesini yapmıştır (Palmer 341). Türk havacılığı bağışlar ile hayat bulurken, savaşların külleri üzerinde gelişmiştir. Bununla birlikte Türkler birçok alanda olduğu gibi havacılık alanında da gelişmelere açık olduklarını göstermişler ve dünyanın ilk hava kuvvetlerinden birini kurmuşlardır. Türk askeri hava gücü, 1911-1914 arasında gösterdiği yüksek performansını savaş yıllarında savaşa göre şekillendirmek zorunda kalmıştır.

Son teknolojiyi kullanan havacilık sahası, alanda önemini ve insanlığın kazanımlarındaki farklılığını sürdürmektedir. Türkiye, havacılığın hemen her alanında birçok gelişmeye öncülük etmiş olmasına rağmen 20. Yüzyılın ilk çeyreğinde katılmak zorunda olduğu ve kesintisiz 11 yıl süren savaşların bir 
sonucu olarak özgünlükte istenilen standartları yakalama imkânı olmamıştır. Askeri havacılık alanında ise dünyanın ilk ve modern sistemlerinden birini teşkil etmiş günümüze kadar bu konudaki hassasiyetini sürdürmüştür. Teknolojideki gelişmeler ve iletişim kolaylıkları ise günümüzde özgünlük alanında da yeni firsatların kullanılmasına daha açı şartların oluşmasına imkân tanımaktadır. Osmanlı hava gücü, dünyanın ilk kurulan hava güçlerinden biri olmanın yanında harekât görevine de ilk katılan hava güçlerinden biridir. Diğer taraftan hava kuvvetlerinin kuruluş yıllarında en uzun süreli (1911-1922) harekata katılan hava kuvveti olma vasfına sahiptir.

\section{Kaynaklar}

\section{Arşiv Belgeleri}

ATASE Arşivi, BDH, Klasör: 1392, Dosya:19, Belge:003-0.

ATASE Arşivi, ISH, Kutu:24, Gömlek:71, Belge:11.

ATASE Arşivi, ISH, Kutu: 69, Gömlek:111, Belge:1.

ATASE Arşivi, ISH, Kutu: 69, Gömlek:115, Belge:8.

ATASE, BDH, Klasör: 1441, Dosya 250, Fihrist 27-5.

ATASE Arşivi, ISH, Kutu:179, Gömlek:30, Belge:1.

\section{Resimlerin Kaynağı}

Hv. K. K.lığı Yeşilköy Müzesi(2012-2016). İstanbul.

\section{Telif ve Tetkik Eserler}

Armaoğlu, Fahir (1999). 19. Yüzyıl Siyasi Taribi 1789-1914. Ankara: TTK Yay.

ATASE (1973). Türk Taribi Silablı Kuvvetleri ve Atatürkçülük. Ankara: Gnkur. Bşk. lığ 150 nci Yıl Yay.

ATASE (1993). Türk Silahli Kuvvetleri Taribi Osmanl Devri Balkan Harbi 2. Cilt

II. Ks. 2. Kitap Şark Ordusu İkinci Çatalca Muharebesi ve Şarköy Çıkarması.

Ankara: Gnkur.

Atatürkçülük Atatürk’ün Görüş ve Direktifleri Birinci Kitap (1984). Ankara: Hv. Bsm.

Aydar, Orhan (1948). Uçan Süvariler. Ankara: Ulus Basımevi.

Danışman, Zuhuri (1971). Evliya Çelebi Seyahatnamesi. İstanbul: Aydın Matbaası. Erdoğan, Mehmet (1986). Hava Gücü ve Savaş. Ankara: Gnkur Bsm.

Flanagan, Brian (2007). Büyük Harp’te Osmanl Hava Kuvvetlerinin Tarihi Erich Serno'nun Hattratı 1914-1918. Çev. H. Tür. Ankara.

Gediz, Ergüder. Türk Hava Kuvvetleri Tarihi C-I (1911-1918). Tarihçe Ş. Yay. Göymen, İhsan (1964). Türk İstiklal Harbi Deniz Cephesi ve Hava Harekatı. Ankara: Genkur.Bsm. 
K. K.lı̆ğ Tarihçe Ş.Md.lüğü (2009). Uçak Albümü 1912-2009. Ankara: Hv.Bsm. ve Neş.Md.lüğü Yay.

Hv. K. K.lığı. Ufukların Ötesindekiler. Ankara: Hv. K. K. Mer. D. Bşk. Hava Harp Tarihi Yay.

Hv. K. K.lığ1 (1982). Türklerin Havacılı̆̆a Hizmetleri. Ankara: Hv. K. K. Mrk. Daire Bşk.lı̆̆ı Harp Tarihi Şubesi Yay.

İlmen, Süreyya (1947). Türkiyéde Tayyarecilik ve Balonculuk Tarihi. İstanbul: İbrahim Horoz Basımevi.

Kansu, Yavuz, Sermet Şensöz ve Yılmaz Öztuna (1971). Havacılık Tarihinde Türkler. Ankara: Hv. Bsm. ve Neş.Md.lüğü Yay.

Keyüsk, Mazlum (1950). Türk Havacılık Tarihi 1912-1914 Birinci kitap. Eskişehir: Uçuş Okulları Yay.

Kocatürk, Önder (2013). Osmanlı Pilotlarının İstanbul-Kahire-İskenderiye Seyehati (Şubat-Mayıs 1914). İstanbul: Boğaziçi Yay.

Kural, Fethi (1974). Kuruluş Yillarında Türk Askerî Belgeleri 1909-1913. Ankara: Hv. Bas. ve Neş. Md.lügü Yay.

Kurter, Ajun (2009). Türk Hava Kuvvetleri Tarihi C.I (1910-1914). Ankara: Hv. K. K.lığı Bsm.

Nikolajsen, Ole (2005). Turkish Military Aircraft Since 1912. Netherlands: Dutch Aviation Society.

Palmer, Alan. Osmanlı Imparatorluğu Son Üç Yüz Yıl Bir Çöküşün Yeni Tarihi. Çev. Belkıs Çorakçı Dişbudak. Yeni Yüzyıl Tarih Dizisi.

Sarp, İrfan (1998). Türk Hava Kuvvetlerinin Doğuş Yılları. Ankara: Hv. Bas. ve Neş. Md.

Süslü, Azmi (1998). “Misak-1 Milli, 1914-1920”. Misak-ı Milli ve Türk Dı̧̧ Politikasında Musul. Ankara: Atatürk Araştırma Merkezi Yay.

Özdemir, Yaşar (1981). Atatürk ve Türk Havacılı̆̆ı. Ankara: Hv. Bsm.

Özdemir, Yaşar (1981). Şehit Pilot Binbaşı Fazıl Bey. Ankara: Hv. Bsm.

Tanman, Sitkı (1953). Türk Havacılık Tarihi İstiklal Harbi (1918-1923). Eskişehir: Hava Basımevi.

Türkmen, Zekeriya (2015). “Türk Havacılık Teşkilatının Kuruluşunda Harbiye Nazırı Mahmut Şevket Paşave Döneminde Gerçekleştirilen Faaliyetlere Bir Bakış”. Havacılık Tarihi Sempozyumu 13-14 Aralık 2012. İstanbul.

Uçarol, Rifat (1988). Tarihi Gelişim İçinde Hava Harp Okulu. İstanbul: Alaş Ofset. Von Kressenstein and Friedrich Freiherr Kress (2007). Son Haçl Seferi Kuma Gömülen İmparatorluk. Çev. Tahir Balaban. İstanbul: Yeditepe Yay.

Yalçın, Osman (2004). Türk Hava Kuvvetleri Teşkilatlanma Tarihi (Cumburiyet Dönemi). Yüksek Lisans Tezi. Ankara: Gazi Üniversitesi.

Yalçın, Osman (2009). Hava Kuvvetleri Filo Tarihçeleri. C. I. Ankara: Hv. K. Bsm. 
ve Neş. Md.lüğü.

Yalçın, Osman (2008). Türk Hava Harp Sanayii Taribi (THHST). Doktora Tezi. Ankara: Gazi Üniversitesi.

Yalçın, Osman (2016). Türk Hava Harp Sanayii Tarihi. İstanbul: Türkiye İş Bankası Kültür Yay.

Yalçın, Osman (2013). Türk Hava Harp Sanayii Tarihi. İstanbul: Türkiye İş Bankası Kültür Yay.

Yalçın, Osman (2017). Türk Hava Gücü Kuruluşu, Yükselişi ve İlk Seferleri (19111950). İstanbul: Türkiye İş Bankası Kültür Yay.

Yılmaz, Veli (2003). Cumburiyet Tarihi I. İstanbul: Harp Akademileri Yay.

\section{Makale ve Süreli Yayınlar}

Aydar, Orhan (1938). "Kaybettiğimiz Hava Kahramanı: Salim İlkuçan'a ait hatıralar".

Beyoğlu, Süleyman (2015). “Türk Havacılığının Doğuş Yılları”. Havacılık Tarihi Sempozyumu 13-14 Aralık 2012. İstanbul.

Ersoy, Ergin (2001). "Göklerden Gelen Tehdit". Hava Kuvvetleri Dergisi, S.339, Ankara.

Hv. K. K.lığı (1927). Hava Mecmuası. 15 Mayıs 1927.

Haber Gazetesi (1936). "Son Ehli Salip Muharebeleri”.

Kayabalı, İsmail ve Cemender Arslanoğlu (1972). "Devlet ve Hükûmet Başkanları ile Türlü Teşekküllerin, Vatan ve Milletin Müdafaası ve Türkiye’de Havacılığın Benimsenmesi Hakkındaki Görüşleri”. Türk Kültürü 116 (Haziran): 1-100. Kasmieh, Khairia (2014). "Suriye Semalarında İlk Türk Uçakları". Türk Hava Kuvvetlerinin 100'üncü Yilı Uluslar arası Tarih Sempozyumu. Ankara. 124133.

Sözeri, Emin Nihat (1961). “Türk Tayyareciliği”. Hava Kuvvetleri Dergisi 202.

Taşdemir, Serap (2014). "The Centery Of The Balkans Wars (1912-1913): Contested Stances Volume II". Avition Activities Ot The Ottoman Empire in The Balkans Wars: 929-940.

Star Gazetesi (2015). “JFK Havalimanı'na Hazerfen'in Mermerden Rölyefi Konuldu”. 25.01.2015.

ŞEHBAL (1914). “Tayyarecilerimiz Port Said'te”, ”Tayyarecilerimiz İskenderiye'de.”, Tayyarecilerimiz Kahire'de”. 98.

Tasvir-i Efkar (1914). “Tayyarecilerimiz Misır'da”. 19 Mayıs 1914 (6 Mayıs 1330). Tasvir-i Efkar (1914). "Tayyarecilerimiz El Ariş'te”. 13 Nisan 1914 (31 Mart 1330). Tasvir-i Efkar (1914). "Yeni Seyehat-i Havaiye İntiahatından”. 6 Mayıs 1914 (23 Nisan 1330).

Turgut, Hüseyin (1955). “Taberya Gölü Kenarındaki Abide”. Uçantürk 1 (Nisan). Uçantürk (1974). "Havacilıkta Türkler IV”. Ağustos 245. 
Uçantürk (1974). "Havacılıkta Türkler”. Ağustos 245.

Ünalp Rezzan (2013). “İstanbul-Kahire Seferi ve Ardındaki Tarihi Gerçek”. Türk Hava Kuvvetlerinin 100'üncü Yılı Uluslararası Tarih Sempozyumu. Ankara. 134-148.

Yalçın, Osman (2012). "Mütareke Dönemi Türk Askeri Havacılığı”. Askeri Tarih Araştırmaları Dergisi 10 (20): 71-96.

Yalçın, Osman (2010). "Türk Havacılık Tarihinde Bağış Uçakları ve Havacılık Sanayii Kurulmasına Tesirleri”. Gazi Akademik Bakış 3 (6): 191-212.

Yalçın, Osman (2011). "Two Important Development Throught The Tuskish History in The 20th Century: The Rising of Aviation and a Leader". Turkish Studies 6/2: 1033-1062.

Yalçın, Osman (2014). “Osmanlı İmparatorluğunun Son Yıllarında Bir Kararlılık Gösterisi: Kitalararası Osmanlı Hava Seferi”. Havacılık ve Spor Dergisi 10: 327-347.

\section{İnternet Kaynakları}

http://www.airnewstimes.com/jfk-yetkililerinden-anlamli-tesekkur-31578-haberi. html (Erişim Tarihi: 22.09.2016).

http://www.airturkhaber.com/haber_detay.asp?haberID=14262, (Erişim Tarihi: 26.01.2014.)

http://www.ensonhaber.com/jfk-havalimani-girisine-hezarfen-ahmet-celebirolyefi-2015-01-24.html (Erişim Tarihi: 22.09.2016).

http://www.hvkk.tsk.tr/tr/IcerikDetay.aspx?ID=20, (Erişim Tarihi: 27 Ocak 2015.) http://www.star.com.tr/guncel/arsiv-haber-994283/ (Erişim Tarihi: 22.09.2016). http://www.tayyareci.com/arsiv/fethibey.asp (Erişim Tarihi: 16.06.2016). 


\title{
Ottoman Empire Period of Turkish Military Aviation*
}

\section{Osman Yalçın **}

\begin{abstract}
Only six years after $17^{\text {th }}$ December 1903 which is accepted as the time of first manned flight by Wright brothers, aircrafts flew by Baron de Catters in a Voisin type plane and Bleirot is a plane carrying his own name appeared in the sky of İstanbul. Ottoman military established a committee to evaluate and investigate those flights. The effects of aircraft in theatre in near future and suggestion of inclusion of aircraft in Ottoman army were cited in the committee's report. A short time later, taking the committee's suggestion into consideration, studies to develop Turkish aviation was started and an "Aviation Commission" was established on $1^{\text {th }}$ June 1911 to work on all aviation issues with a full authority. Many problems like organization, pilot, observer, equipment, technical training, purchase of aircraft, and decision for a place of aviation, air defense requirements and manufacture of aircraft with national resources and abilities were investigated and significant steps were taken. Establishment and organization of the process of the Ottoman aviation is investigated in this study. In this context; the reasons of the establishment of Ottoman military aviation, organization, personnel supply, airplane, balloon and the supply of equipment, efforts to establish the aircraft factory, operational tasks and the influence of the cooperation of Turkish aviation with the Germans were investigated. Certainly the results obtained from the study are that the first core of Turkish Air Force started with a four man aviation commission in 1911 and it became an independent air force in 1944, just in 33 years.
\end{abstract}

\section{Keywords}

The Ottoman Aviation, Turkish Air Force, Süreyya Bey, airgraft, balloon, Tripoli War, Balkan Wars.

\footnotetext{
Date of Arrival: 04 April 2016 - Date of Acceptance: 05 April 2017

You can refer to this article as follows:

Yalçın, Osman (2021). "Osmanlı İmparatorluğu Dönemi Türk Askeri Havacılığı”. bilig - Journal of Social Sciences of the Turkic World 96: 147-176.

** Assoc. Prof. Dr.(E.)Hv.Öğ.Kd.Alb., Istanbul Rumeli University, Vocational School, Transportation Services, Civil Air Transportation Management - İstanbul/Turkey

ORCID ID: 0000-0002-6259-6490

osman.yalcin@rumeli.edu.tr
} 


\title{
Турецкая военная авиация в период Османской империи Осман Ялчын
}

\begin{abstract}
Аннотация
Всего через шесть лет после 17 декабря 1903 года, когда был совершен первый полет самолета братьев Райт, в небе над Стамбулом уже совершили полеты Барон Пьер де Катерс на самолете модели «Вуазен», а вслед за ним Луи Брелио на самолете собственной компании. Османские военные сформировали комиссию и изучили этот вопрос, и в их отчете прозвучала идея участия в османской армии авиации в ближайшем будущем ввиду ее чрезвычайной важности. Вскоре началась работа по созданию турецкой авиации, и османская авиация родилась с образованием 1 июня 1911 года «Авиационной комиссии». Многие проблемы, такие как организация, подготовка пилотов, летная и техническая подготовка, закупка самолетов, решение о размещении авиационных центров, потребности в оборудовании и противовоздушной обороне, и собственное производство самолетов были решены в короткие сроки, и были предприняты важные шаги. В данном исследовании рассмотрено создание и организация османской авиации. В данном контексте были изучены предпосылки создания Османской военной авиации, организация, снабжение персоналом, поставка самолетов, воздушных шаров и оборудования, усилия по созданию авиационного завода, оперативные обязанности и влияние сотрудничества с немцами на турецкую авиацию. Безусловно, итоги, полученные в результате исследования, заключаются в том, что первое ядро ВВС Турции началось с авиационной комиссии из четырех человек в 1911 году и стало независимыми военно-воздушными силами в 1944 году, всего за 33 года.
\end{abstract}

\section{Ключевые слова}

Османская авиация, ВВС Турции, Сюрейя Ильмен, самолет, воздушный шар, Итало-турецкая война, Балканские войны.

\footnotetext{
" Поступило в редакцию: 04 апреля 2016 г. - Принято в номер: 05 апреля 2017 Ссылка на статью:

Yalçın, Osman (2021). “Osmanlı İmparatorluğu Dönemi Türk Askeri Havacılığı”. bilig - Журнал Гуманитарных Наук Тюркского Мира 96: 147-176.

** Доц., д-р, Стамбульский университет Румели, Профессиональная школа, Управление транспортом и гражданскими перевозками - Стамбул / Турция ORCID ID: 0000-0002-6259-6490

osman.yalcin@rumeli.edu.tr
} 